九州大学学術情報リポジトリ

Kyushu University Institutional Repository

\title{
Kusama Yayoi in the Context of Eastern and Western Thought
}

\section{Pachciarek, Pawel}

Adam Mickiewicz University : Doctoral Candidate | Osaka University : Mext Scholarship Phd Fellowship

https://doi.org/10.5109/1806126

出版情報: Journal of Asian Humanities at Kyushu University. 2, pp.1-14, 2017-03. Kyushu University, School of Letters, Graduate School of Humanities, Faculty of Humanities バージョン:

権利関係 : 


\title{
Kusama Yayoi in the Context of Eastern and Western Thought
}

\author{
PAWEL PACHCIAREK
}

$\mathbf{W}$ RITINGS on the creative world of Kusama Yayoi (b. 1929) occasionally inquire into the possible ties between her art, the art of other artists, and certain philosophical or religious systems. It is difficult to reach an unambiguous resolution on such matters, as the artist herself frequently emphasizes the "self-birth" of her actions, viewing them as set outside any type of context. ${ }^{1}$ That said, we can still discern a certain closeness between Kusama's creativity and particular philosophical and religious references. This article explores the presence of such references in Kusama's

The author would like to thank Lindsey E. DeWitt for her insights and editorial assistance.

1 Kusama may prefer that the viewer look at her works in a non-discursive manner, free of any context, but she nevertheless does not-in public statements, manifestos, or interviews-discount the influence of minimalism and pop art on her formative years. The artist admits ties to other artists and groups such as Zero Group, alongside of whom she occasionally showed. These connections were especially strong during her New York residency. Still,

Kusama never joined any single artistic group nor did she aspire to, preferring rather to keep her artistic expression free from any restrictions and liberated from an overly contextualized world

of fabricated histories. See Midori Yamamura's comprehensive study on the historical and social-political contexts of Kusama's actions during her time in the United States. Yamamura casts new light on many details of the artist's life and works. Midori Yamamura, Yayoi Kusama: Inventing the Singular (Cambridge, MA: The MIT Press, 2015). works, which in a unique manner intertwine her private life, imagination, and experiences as an artist. The first part of the paper considers Kusama's artistic universe from the perspective of Western philosophy, employing it as an interpretative tool to better understand certain aspects of specific art works. Kusama's time living in America and visiting Western European countries marks some of her most prolific periods of artistic output, warranting a closer look at some of her works from a Western perspective. I tease out connections between ideas expressed by a Japanese artist coming to New York in the late 1950s (Kusama's self-obliteration and the polka dot), Anaximander's ancient Greek philosophy, and Nietzschean philosophy. Next, I shift focus to Kusama's more Eastern-leaning views, specifically on infinity and enlightenment, and explore potential Zen Buddhist influences in her unpublished play script "The Gorilla Lady" and her distinct, meditative approach to painting. Finally, I discuss Kusama's works in the context of Japanese psychiatrist-collector Takahashi Ryūtarō’s "Mindfulness!" exhibition series.

\section{The Arche of Dots}

Dots-transformed in a variety of forms and woven into an intricate and continuous symbiosis, figuratively 
representing a phantasmic world of imaginationrepresent for Japanese artist Kusama something akin to what Greek philosophers perceived as the source, origin, or root cause. Kusama's vision of the universe draws on the architectonic notion that singularity is already a message of multitude from its intrinsic concept. Dots (and even a single dot), it follows, can be said to represent the very fabric of life. ${ }^{2}$

Consider the basic, obsessive element of the artist's fears in light of Greek philosopher Anaximander's (c. 610-546 вСE) philosophical wanderings on origin (arche) and the infinite (apeiron): "all things come from single primal substance ... it is infinity, eternal and ageless, and it encompasses all the worlds." 3 Significantly, infinity for Anaximander signifies the quality of arche but not its substance, unlike theories put forth by other Greek philosophers (e.g., water for Thales, fire for Heraclites, air for Anaximenes); nor does it single out quality as distinct from unity. The qualitative neutrality of arche is in fact a condition for the continuous existence of a certain (just) order of the cosmic universe. In this paradigm, everything is contained in infinity and everything also emerges from it. Infinity is simultaneously the beginning and the end - an endless potential, a cyclic and inexhaustible creation of objects. Anaximander's universe, awakened by this infinite reason, continuously evolves. We can consider Kusama's dots, which manifest in various forms in many of her artistic works, as representations of her infinity, in much the same way.

On the streets of New York in the second half of the 1960 , Kusama chose dots as her weapon of choice to address and attack what she viewed as an oppressive political and cultural establishment and also to inspire revolutionary social changes that would be rooted in love, peace, and tolerance. Kusama held a series of naked happenings that featured different colored dot designs being painted on the bodies of participants. ${ }^{4}$
This act, per the artist's stated intentions, represented symbolically the path toward experiencing the quality of the infinite universe. By painting dots on the body, Kusama believed men and women could experience, return to, and be at one with the universe, and in so doing vanish from the multitude and become a potential force in subsequent transformations (figure 1). In 1968, she wrote:

Polka dots can't stay alone, like communicative life of people, two and three and more polka dots become movement. Our earth is only one polka dot among a million stars in the cosmos. Polka dots are a way to infinity. When we obliterate nature and our bodies with polka dots, we become part of the unity of our environment. I become part of the eternal, and we obliterate ourselves in Love. ${ }^{5}$

Arche, a term that seems to be inseparably tied with the dot, for Kusama signifies a process of self-obliteration, a type of a spiritual enlightenment characterized by a renewed connection with infinity. The term is strongly tied to Kusama's naked happenings of the 1960s, where polka dot patterns, painted on a body, were to cause self-obliteration. Self-obliteration paves the way to salvation by allowing humans to free themselves from the shackles that tie them to humanity, shackles such as history, ego, and imposed social roles. In self-obliteration, we see Kusama's ponderings on some of the most significant slogans propagated in the American counterculture of the late 1960s: free love, anti-military social movements, and new (to America) streams of philosophical and religious thought, much of which were drawn from East Asian traditions. As noted by art historian Midori Yoshimoto:

In essence, Kusama's Self-Obliteration is a creative hybrid of Buddhist thought inflected with New

2 "Dots might represent the circle of the earth, or the sun or moon, or whatever you like." Yayoi Kusama, trans. Ralph McCarthy, Infinity Net:The Autobiography of Yayoi Kusama (London: Tate Publishing, 2011 [2002]), 102.

3 Bertrand Russell, History of Western Philosophy (London and New York: Routledge Classics, 2006), 35

4 Kusama used the term "Happening" (with a capital $\mathrm{H}$ ) for most of her public performances from the 1960s and 1970s. I follow this style here, and refer to her other performances and events as "happenings" (with a lower-case h). Kusama borrowed the term "Happening" from artist Alan Kaprow, who first used it in 1959, but employed it more casually, as her performances did not have

as complete a script as Kaprow's did but were focused rather on attracting instant attention from onlookers who could be brought into the performance. For more on the connection between Kaprow and Kusama, see Midori Yoshimoto, Into Performance: Japanese Women Artists in New York (New Brunswick: Rutgers University Press, 2005), 69.

5 Kusama Yayoi, quoted in Jud Yalkut, "Polka Dot Way of Life (Conversations with Yayoi Kusama)," New York Free Press 1, no. 8 (1968): 9 


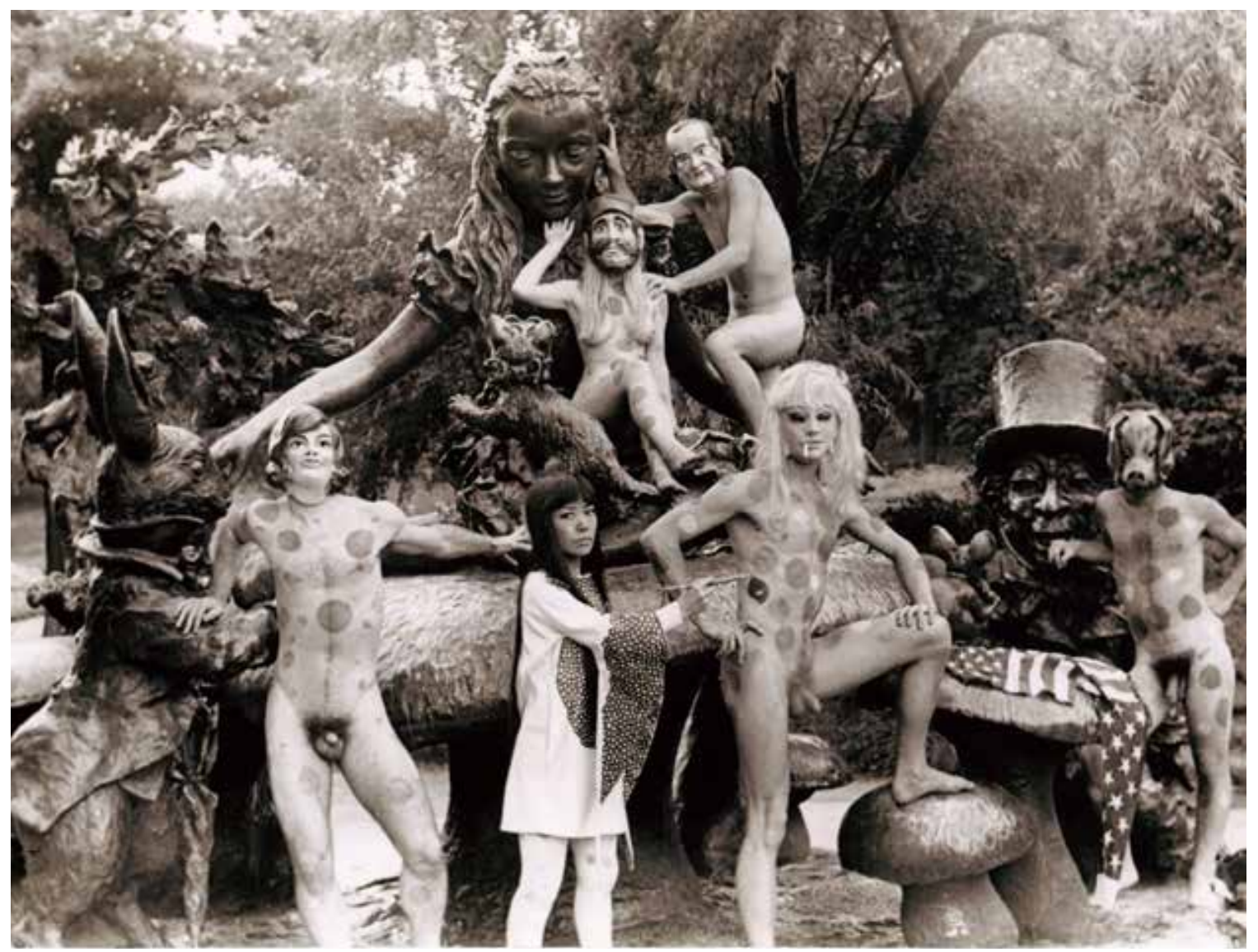

Figure 1. Anatomic Explosion Happening. August 11, 1968. Photography. Alice in Wonderland sculpture, Central Park. OYayoi Kusama.

Age spiritualism, the rhetoric of sexual liberation, and her semi-autobiographical narrative. ${ }^{6}$

Yoshimoto's likening of self-obliteration to Buddhist thought points to a specific context and moment in the artist's life. When Kusama arrived in New York in 1958, Eastern philosophy, and Zen Buddhism in particular, was already influencing prominent artists such as Mark Tobey (1890-1976), Merce Cunningham (1919-2009), and John Cage (1912-92). The voluminous writings in

6 Midori Yoshimoto, "Kusama Saves the World through Self-Obliteration" (Self-published, 2011), 3, www.Academia.edu/2092612/ Kusama_Saves_the_World_through_Self-Oblitaration_English_ version (accessed January 20, 2017).
English by Western-influenced Japanese philosopher Suzuki Daisetsu 鈴木大拙 (1870-1966) - often viewed as the "founding father" of Zen in the West-contributed greatly in this regard. Kusama undoubtedly would have witnessed the popularity of and demand for Zen, especially among the younger generation of artists and intellectuals in New York. $^{7}$ By explaining Kusama's self-obliteration as some sort of merged construct of various elements, however, Yoshimoto construes this concept as a product of "Beat Zen" or "Square Zen," a Western quasi-Zen often criticized as a bastardized version of the actual East Asian traditions. ${ }^{8}$ For example, Ruth Fuller Sasaki (1892-1967), an American woman who became an abbess of Ryōsen'an 龍泉庵 (a

\footnotetext{
7 See Helen Westgeest, Zen in the Fifties (Chicago: Reaktion Books, 1998).

8 See Alan Watts, Beat Zen, Square Zen, and Zen (San Francisco: City Lights Books, 1959).
} 
sub-temple of Daitokuji 大徳寺 in Kyoto), comments in the following manner on the Zen boom in the West:

\begin{abstract}
Zen is invoked to substantiate the validity of the latest theories in psychology, psychotherapy, philosophy, semantics, mysticism, free-thinking, and what-have-you. It is the magic password at smart cocktail parties and bohemian get-togethers alike. ... How far away all this is from the recluse Gautama sitting in intense meditation under the Bodhi-tree trying to find a solution to the problem of human suffering! ${ }^{9}$
\end{abstract}

As I hope to demonstrate below with the examples of Kusama's pumpkin contemplation and messianic mission, we should distance the artist from the "Zen flâneur" image found in the United States' counterculture of the 1950 and 1960 s. After all, "Zen arts without Zen study is just cultural junk," one Zen master who gained prominence in the West remarked. ${ }^{10}$

Kusama has repeatedly emphasized in interviews and her writings that the self-obliteration concept should not be directly identified with any idea or a religious doctrine, however. Its foundation is anti-contextual, she claims, arising from her imagined vision of the world. ${ }^{11}$ And yet, in attempting to comprehend the self-obliteration process, it is difficult to discount entirely the potential influences of external "contexts."12 On more than one occasion and seemingly not as an intentional game with the viewer, the artist herself has noted multiple tracks of mythical (religious) or cultural thinking. In a 1994 interview, for instance, when asked about the meaning of self-obliteration, Kusama replied:

9 Gregory Levine, "Two (or More) Truths: Reconsidering Zen Art in the West," in Awakenings: Zen Figure Paintings from Medieval Japan, eds. Gregory Levine and Yukio Lippit (New York: Japan Society, 2007), 54-5.

10 Yasuda Joshu Dainen Roshi, "Zen and Culture," Zenmai 8, http:// wwzc.org/dharma-text/zen-and-culture (accessed January 10, 2017).

11 For instance, Kusama wrote in the 1960s: "If there is any Zen in my work, I am unconscious of it." CICA/YK/6000.08.Kusama Archive. CICA codes were applied to Kusama's papers and interview tapes for Kusama's 1989 exhibition at the Center for International Contemporary Arts (CICA), New York.

12 American critic John Kroll described the Infinity Nets series as a "Zen vigil." Jack Kroll, "Reviews and Previews: Yayoi Kusama," Art News 60, no. 3 (May 1961): 15. Quoted in Claudia Ponton, "Between Death and Life: Trauma in the Art of Yayoi Kusama" (MA thesis, University of Oregon, 1999), 4
[Self] always revives and reemerges as in eigō kaiki 永劫回帰 (Eternal Recurrence). That is the meaning behind Self-Obliteration. ${ }^{13}$

The artist's words immediately recall Friedrich $\mathrm{Ni}$ etzsche's (1813-49) concept of "eternal recurrence."14 Considering Kusama's explicit association of the "eternal recurrence" concept in light of the aforementioned immanent-to-nature principle (arche) propagated by the Ionic nature philosophers may lead to a fuller understanding of the artist's universe. Kusama's acceptance of "eternal recurrence" signifies that for her the entire universe is infinite, having no beginning and no end. It must therefore contain the forces that sustain its own existence. And if it is self-sufficient, then all forms of the phenomenal world can be found in its singularity. Here, a cycle of recurring returns and births replaces a linear notion of time (figure 2).

But we cannot totally reconcile Kusama's use of "eternal recurrence," and thus her vision of the world, with Western philosophical ideas. While Nietzsche speaks about the utterly physical character of "eternal recurrence," Kusama outlines a vision of the universe completely penetrated by a metaphysical, spiritual characteristic. This is most visibly expressed in her self-obliteration concept: "I want to see my life, which is but one dot. The dot-or rather, the single particle out of a million - is my life."15 Kusama, who has long struggled with her psychological sense of self, views herself as a being living on the border of two worlds: the real world and the unreal world. Struggling with depersonalization allowed Kusama to traverse between the two worlds and create from that space of liminality. The first signs of such a state can be traced back as early as 1950 with her painting Accumulation of the Corpses (Prisoner Surrounded by the Curtain of Depersonalization), which she describes in her 2002 autobiography as drawing on experiences during her youth of depersonalization neurosis:

13 Kusama Yayoi, "Atorie hōmon Kusama Yayoi," Co $\bullet a \bullet$ Bo Art 2 (1994): 49.

14 This idea can be traced as far back as ancient Egypt, where images of scarabs, which are regarded as symbols of an unending cycle of rebirths, have been found in tombs and on amulets. See more about scarabs and their incorporation into Egyptian symbolism, religion, and art in Richard H. Wilkinson, Egyptian Scarabs (London: Shire Publications, 2008).

15 Ikai Hisashi, "Mizutama ni komerareta imi o tokiakasu," in Yappari suki da! Kusama Yayoi, ed. Pen Henshūbu (Tokyo: Hankyū Komyunikēshonzu, 2011), 52. 


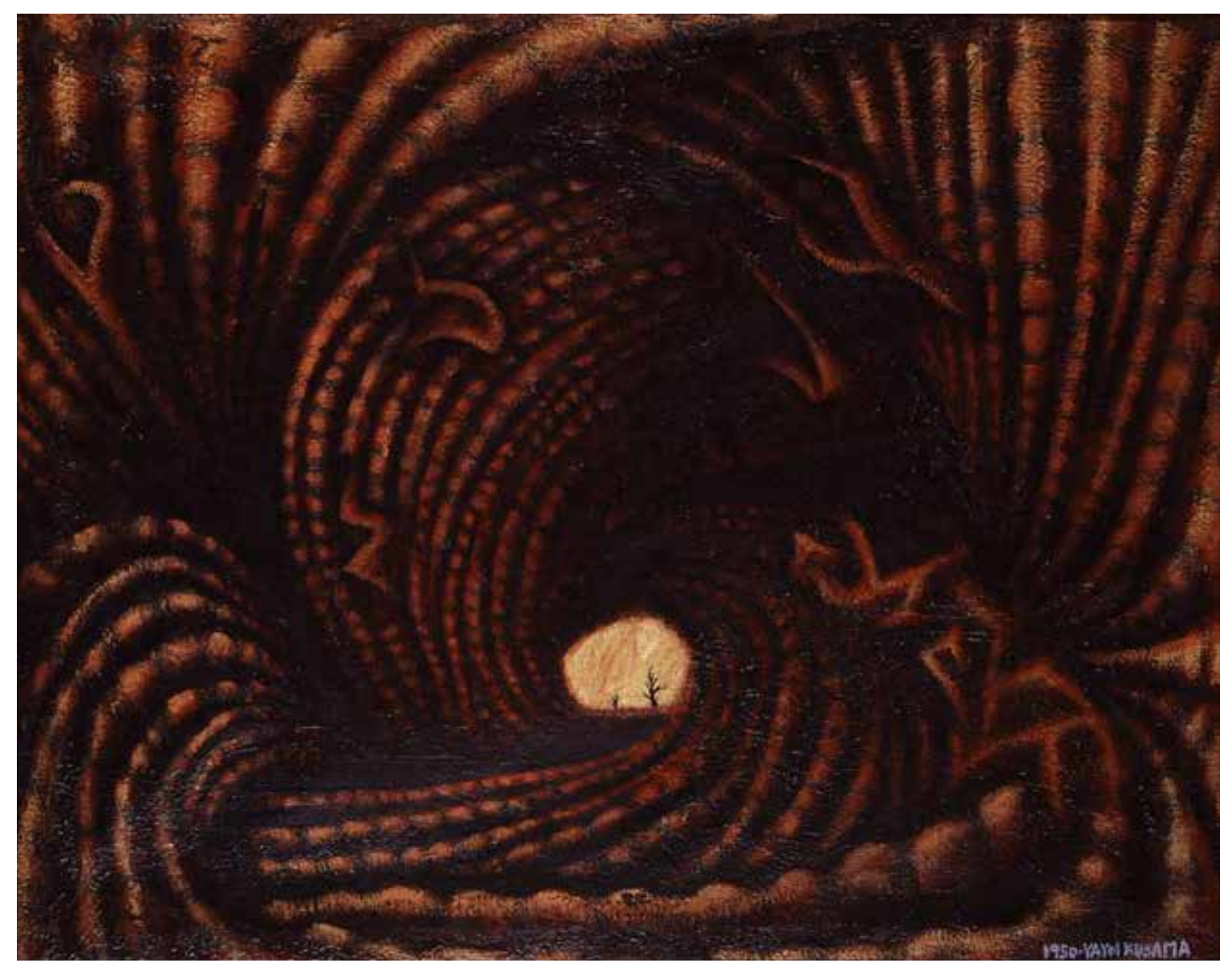

Figure 2. Kusama Yayoi. Accumulation of the Corpses (Prisoner Surrounded by Curtains of Depersonalization). 1950. H. $72.3 \mathrm{~cm}$, w. $91.5 \mathrm{~cm}$. Oil and enamel on seed sack. The National Museum of Modern Art, Tokyo. (YYayoi Kusama.

I felt as if I am in a place where pleated, striped curtains enclose me, and finally I am in a place where pleated, striped curtains completely enclose me, and finally my soul separates from my body. Once that happens, I can take hold of a flower in the garden, for example without being able to feel it. Walking, it is as if I am on a cloud; I have no sense of my body as something real. ${ }^{16}$

16 Kusama, Infinity Net, 87.
A split world can never fully reflect "eternal recurrence," however, at least not as Nietzsche articulated it in terms of the physical nature of existence. Dividing the physical world into more than one enduring dimension can only be possible if each next one is merely a reflection, a cyclic repetition drawn from the same physical properties. For Nietzsche, the universe is composed of a finite number of beings (and their transformations), which are infinitely reproduced in cycle after cycle. All things thus represent a repetition of existence in a cyclic time. This does not align with the constant and infinite transgression of matter and souls we find in Kusama's world. The unstoppable transformation of one quality into another, stretched in boundless time, is precisely what constitutes the basis of eternal existence for Kusama. The dot, principle symbol of this process, may undergo countless transformations: "a polka dot has the form of the sun which is a symbol of the energy of the whole 
world, and also the form of the moon which is calm." ${ }^{\text {"17 }}$ Beyond “eternal recurrence" (eigo kaiki 永劫回帰), then, this process of constant movement and change seems to resonate strongly with the Buddhist notion of transmigration (rinne tensho $\bar{o}$ 輪廻転生).

\section{Face to Face with a Pumpkin}

Let us also consider more closely the latent (and obvious) connections between Kusama's art and Zen Buddhism. In 1948, upon commencing studies at the Kyoto Municipal School of Arts and Crafts, Kusama rented a room and in it painted numerous representations of a pumpkin with a great dedication bordering on madness. ${ }^{18}$ This would, in later years, become an important and internationally recognizable motif. Kusama's creative process involved, if not depended upon, specific rituals. Before dawn, she would lay out her painting tools on the carpet along with sheets of vellum paper; then, and before painting, she practiced Zen meditation.

When the sun came up over Mount Higashiyama, I would confront the spirit of the pumpkin, forgetting everything else and concentrating my mind entirely upon the form before me. Just as Bodhidharma spent ten years facing a stone wall, I spent as much as a month facing a single pumpkin. I regretted even having to take time to sleep. ${ }^{19}$

Kusama's self-comparison with Bodhidharma (Jpn. Daruma 達磨), first patriarch of Zen Buddhism, sheds new light on the entire project. For Kusama, who "lives in the space between subjectivity and objectivity" betwixt the real and the unreal, painting represented a self-imposed mission, one she sought to accomplish through practically non-stop output of works. ${ }^{20}$

Central to this "mission" is the message of bringing love and peace into the world. One of the most expressive examples of Kusama's utopian vision can be found

17 Kusama, quoted in Jud Yalkut, "Polka Dot Way of Life," 9.

18 Present-day Kyoto City University of Arts. At the time, Kusama lived on a mountain slope in a haiku poet's house together with her family.

19 Kusama, Infinity Net, 76

20 Takiguchi Shūzō, "Yōseiyo eien ni," in Manhattan jisatsu misui jōshūhan, ed. Kusama Yayoi (Tokyo: Kadokawa Bunko, 1984), 348. in her Happenings, such as the one held in front of the main headquarters of New York's Election Commission in November 1968. A week after stormy presidential elections, and in the shadow of the Vietnam war, Kusama arranged a public reading of a letter to Richard Nixon, victorious candidate of the Republican Party. In the letter, titled "An Open Letter to My Hero, Richard M. Nixon," the artist expressed her radical, pacifist convictions. She prepared to give her body to the President so that he could tame his "male, battling spirit" and understand the "naked truth," that violence is impossible to eradicate using violence. ${ }^{21}$ Spinning her own vision of a world free of hatred, Kusama writes:

Our earth is like one little polka dot, among millions of other celestial bodies, one orb full of hatred and strife amid the peaceful, silent spheres. Let's you and I change all of the peaceful, silent spheres. Let's you and I change all of that and make this world a new Garden of Eden. ${ }^{22}$

Let us also consider the prophetic role of "World Savior" Kusama took upon herself in the "Kusama Polka Dot Church" (1968). In a spacious loft on Walker Avenue in SoHo, Kusama, the church's self-appointed "High Priestess of Polka Dots," set forth a simple dogma: to spread the ideas of love and reconciliation throughout the world. Her followers' first sacramenttheir baptism - consisted of being painted with dots all over their naked bodies as a means for them to "return to the root of their eternal soul." "It is the moment of joy and of inheriting the vitality of infinity." ${ }^{24}$ In November 1968, Kusama held another Happening called Homosexual Wedding (figure 3). The invitations and press announcement stated that Kusama, "The High Priestess of Polka Dots," would conduct a marriage ceremony for a homosexual male couple. During the

\footnotetext{
21 Yayoi Kusama, "Open Letter to My Hero, Richard M. Nixon," November 11, 1968. Recalling again Anaximander's arche, the stated first principle could not have a defined polarization, as it would draw others and at the same time engage with them in continuous battle. As Russell points out, "the primal substance could not be water, or any other known element. If one of these were primal, it would conquer the others. ... the primal substance, therefore, must be neutral in this cosmic strife." Russell, History of Western Philosophy, 36.

22 Kusama, "Open Letter to My Hero."

23 Yayoi Kusama, "The Artist's Voice Since 1981," conversation with Turner Grady, Bomb (Winter 1999): 12.

24 Kusama, "Open Letter to My Hero."
} 


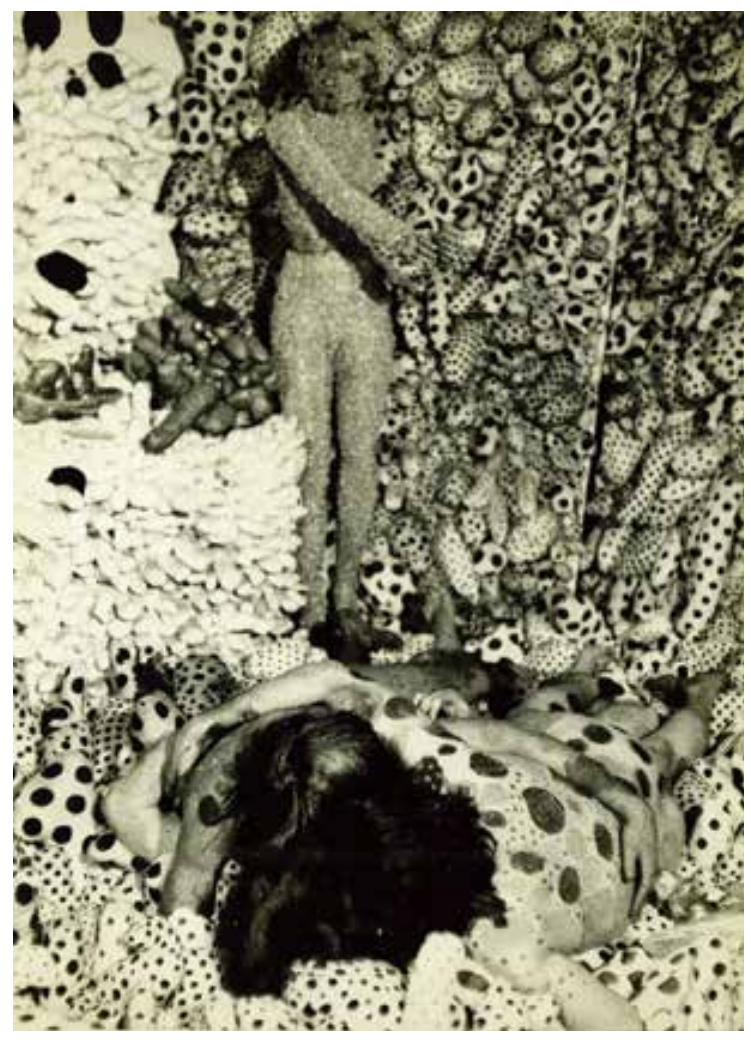

Figure 3. Homosexual Happening. 1968. Photography. Kusama's studio. (CYayoi Kusama.

ceremony, the two grooms wore a one-piece orgy gown designed by Kusama especially for the occasion. It was one of many completed avant-garde fashion design projects that would soon be created by "The Kusama Fashion Company." ${ }^{25}$

\footnotetext{
25 As a young girl, Kusama wore clothes she designed herself and later, when in New York, she started a company to produce two types of designs: some we might consider as haute couture, such as an evening dress for $\$ 1,200.00$ with open cuts on the breasts, buttocks, and vagina; and cheaper clothes sold for as little as $\$ 15.00$ such as the "The Homo Dress," which also featured cutouts in the buttocks area. Designs from Kusama's "See-Through" and "Way Out" brands became popular among the rich, jet-setting clientele for whom Kusama opened a luxury boutique on Fifth Avenue. "The best way of looking human is to go around completely nude, but if you must wear clothing and still want to look individual, wear hand-made things." Kusama first tried her hand at sewing when she was a teenager during World War II. She was assigned to work on the production of parachutes in the Kuraha textile factory in Matsumoto. Designs consisting of a single piece of clothing worn at the same time by two or more
}

Establishing her own religious group was more than an attempt to preach ideas of free love and tolerance. Although rudimentary in form, Kusama's church was a project that inquired into how the church, a social institution, could fight social inequality, hatred, and acts of violence against people with different skin color, religious beliefs, or sexual orientation. Homosexual Wedding stands as a proscription against oppressive and heteronormative discourse, something Kusama viewed the Church as transgressing. The artist becomes in this case an anti-priestess of the Church-her own vision of a savior wanting to rescue everyone, even (and especially) those who were excluded.

The purpose of this marriage is to bring out into the open what has hitherto been concealed... Love can now be free, but to make it completely free, it must be liberated from all sexual frustrations imposed by society. Homosexuality is a normal physical and psychological reaction, neither to be extolled nor decried. It is abnormal reaction of many people to homosexuality that makes homosexuality abnormal. ${ }^{26}$

\section{Infinity Nets}

In 1958, Kusama created a series of works sourced from the hallucinatory experiences that conditioned her perspective on infinity:
Everything - I, others, the entire universe - would be obliterated by white nets of nothingness connecting astronomical accumulations of dots. White nets are enveloping the black dots of silent death against a pitch-dark background of nothing- ness. $^{27}$

In these works, we find a resemblance (reflected in the title, Pacific Ocean, given to some of the works in the series) to the surface of the Pacific Ocean as viewed

\footnotetext{
people and designs with cutouts in sensitive areas became for Kusama a way to promote free sexuality. Yayoi Kusama, "Nudist Queen Designs Clothes for Department Store," Press release, Kusama Fashion Incorporated, April 1969.

26 Kusama, "Homosexual Wedding," Press release, Kusama Polka Dot Church, November 25, 1968

27 Kusama, Infinity Net, 23.
} 
from an airplane: an unending string of dots, and the nets formed from them, which give the impression of continuous repetition and division as well as unstoppable movement through visible brush strokes and irregularities in the shapes of dense circles. ${ }^{28}$ The oppressive monotony of the strain of creation is clearly visible, as the gesture and the creative process itself seems to become more important than the final result. The same motif appears in much later works from 2005 as well, for which the artist used canvases similar in size to the heroic period of her first Infinity Nets (figure 4). ${ }^{29}$ Kusama describes her brush strokes as "repeated exactly in monotone, like the gear of a machine." ${ }^{30}$ Many video-recorded images show the artist, even today, immersed in a deep and meditative concentration while she creates. The dot represents for Kusama the unique basis for her imagined world. We might also think of it as a non-subjective method of seeing; a cleansing of the mind from figures and objects. A similar imagining of (non)thinking can be found in zazen meditation.

Kusama's experience reveals itself as a reversal of the whole, built from the multitude philosophy of Greek philosopher and author of atomic theory, Democritus (ca. 460-370 BCE), into a state of continuous scattering, continuous movement of matter, and an unfinished number of nets and dots that is impossible to grasp. Her creativity, an unceasing gesture of repetition, includes in this fog of dots her ego (in accordance with the Western notion of ratio). A body covered with dots no longer has individual or personal qualities; it is no longer a self in the understanding of Descartes' philosophy. It does not succumb, therefore, to the experience of a single unit or to the repression of the government. Self simply vanishes.

In Kusama's performative acts of painting dots on

28 A few of the works from the Infinity Nets series were named "Pacific Ocean." In 1958, when Kusama wrote from Seattle to a newspaper in Nagano about her trip to the United States, she recalled the details of her flight, in particular the moment she saw the Aleutian Islands while crossing the Bering Sea and the Pacific Ocean, when the ultramarine waters of the Pacific Ocean shone through the completely white clouds. Kusama noted that she finds a similar element of "illusion" in her own works. Kusama Yayoi, "Shiatoru tayori," Nanshin nichi nichi shinbun, January 30, 1958

29 The recent showing of Kusama's Infinity Nets is less a simplistic repetition of its inaugural run half a century ago than a non-semantic marking of Kusama's private world-the continuous repetition of certain elementary particles.

30 Louise Neri, ed., Yayoi Kusama (New York: Rizzoli, 2012), 62.

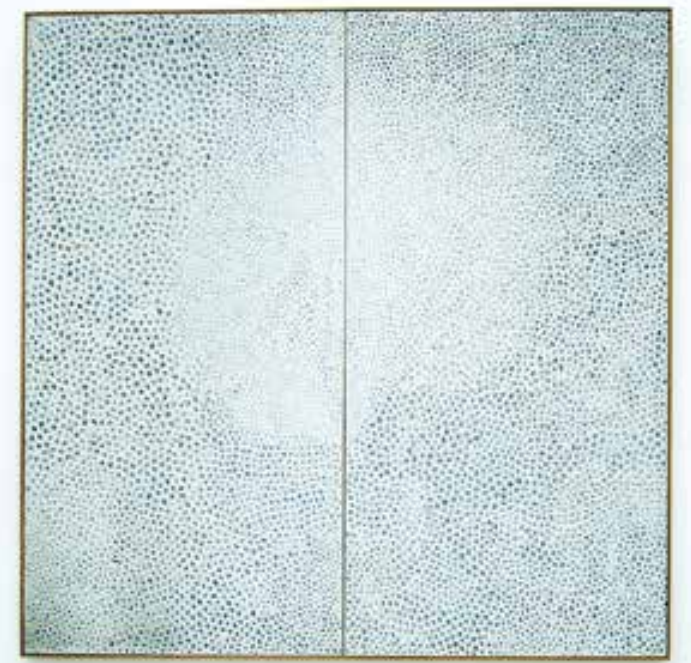

Figure 4. Kusama Yayoi. Pacific Ocean. 1960. H. $116.7 \mathrm{~cm}$, w. $91 \mathrm{~cm}$. Oil on canvas. @Yayoi Kusama.

a naked body, too, we see the "obliteration of a given person and its return to the natural universe."31 The dot acts as an empty symbol, unmarked. The dot is Kusama's signature, and signature, for French philosopher Jacques Derrida (1930-2004), marks a "trait of self." ${ }^{2}$ In the context of Kusama's creativity, however, the signature acts less as a "trait of self" than a means by which the artist can scatter her identity (and the identity of others). In the Zen Buddhist tradition, the notion of obliteration, conceived of as emptiness $(k \bar{u}$ 空), requires that one drop any sense of self and enter into a state of no-self. ${ }^{33}$ The realization of emptiness

31 Kusama, Infinity Net. 102

32 "By definition, a written signature implies the actual or empirical nonpresence of the signer.... in order to function, that is, to be readable, a signature must have a repeatable, utterable, imitable form; it must be able to be detached from the present and singular intention of its production." Jacques Derrida, trans. Adam Dziadek and Pawel Janusz Margański, Marges de la philosophie (Warsaw: Wydawnictwo KR, 2002), 402.

33 " $K \bar{u}$ (emptiness) is not emptiness in a negative understanding of the word, where there is nothing ( $m u$, nothingness), it is not static emptiness, unchanging and clotty. This is a positive emptiness, dynamic, filled with unmeasurable energy. Emptiness is complete power.... the state of $k u$ is a perfect and complete preparedness," Claude Durix, Cent clés pour comprendre le zen (Paris: Courrier du Livre, 1991), 213, my translation. 
and the attainment of enlightenment in the Buddhist context ends with nirvana, the state of literally "blowing out" (obliterating?) the flame of emotional and psychological defilements and exiting the realm of rebirth. Unlike nirvana, however, Kusama's obliteration is a never-ending process. She continues to paint as the atomic details leave the body, connecting and scattering simultaneously. For the artist, this stands as a metaphor for the continuous radiating out of the universe and the specific communion of bodies torn from the thinking ego. Perhaps Kusama's notion of obliteration simply represents a form of meditation - being for the sake of being.

In Kusama's works we can thus discern fragments of a Buddhist way of thinking, one based on the idea of freeing oneself from the shackles of determinism that limit and even define the individual and personal ego, which is intensified by her personal experiences and hallucinations and then represented in dot form. Dots may then serve as a post-modern artistic presentation of the no-self (muga 無我) stage of enlightenment, wherein one has achieved awareness of the lack of self, rejects the self, and does not even remember that one once had an ego or self. ${ }^{34}$

\section{Gorilla Lady}

We find perhaps the clearest connection between Kusama's art and Buddhism in her literary output. A direct reference can be found, for example, in a never-realized play titled "The Gorilla Lady Meets the Demons of Change: A Gen'ei/Zen Farce." ${ }^{35}$ The subtitle "Zen Farce" clearly points to Buddhist influences, but it is not clear how "Buddhist" Kusama's initial ideas for the play were or how much they were shaped by her collaboration with friend and art critic Gordon Brown. ${ }^{36}$ Neverthe-

\footnotetext{
34 Durix, Cent clés pour comprendre le zen, 79.

35 A letter to Kusama Productions from Kenneth Waissman of Waissman \& Fox Inc., dated October 12, 1972, states that the screenplay was submitted to a Broadway theatre company but it was rejected because "(it) did not excite (them) enough to go further with it." Yayoi Kusama Archive.

36 Kusama met Brown in 1963 during an interview. From that moment on, he became her close co-worker and assisted her in editing declarations as well as texts, which she prepared for the press and for exhibits in which she participated. See Midori Yamamura, "Re-Viewing Kusama 1950-1975: Biography of Things," in Yayoi Kusama Mirrored Years, ed. Franck Gautherot (Dijon: Le Consortium, 2009), 68
}

less, certain Buddhist references are obvious: one character in the play is a Zen Master and the names of the three demons of change are Karma, Dharma, and Kannon. Despite their names, demons are evil entities who manipulate a three-meter-long vinyl snake that "winds and squirms down the aisle; he tickles the audience and plays tricks with them." ${ }^{37}$

"The Gorilla Lady Meets the Demons of Change," set in Tokyo in 1947, was planned as a play in three acts. Kusama, who was also to appear in the play, is presented as "sexual virgin sacrifice to the Snake" or as the "Gorilla Lady." In the last act, Kusama is eaten by a snake marionette.

ZEN MASTER (to Kusama): Your only escape from the sordid desires of this world lies in self-obliteration...endless nothingness... and infinite emptiness.

Kusama gives up the struggle and the snake swallows her. The warrior rushes in and cuts the snake in half. The two halves of the snake separate and Kusama is reborn as a child dressed in white, the color of innocence and purity (recall here Kusama's mission as the savior, her self-sacrifice signifying the overcoming of dark forces). The two halves of the snake then chase each other around the stage and finally exit in different directions. ${ }^{38}$ In this scene we find a direct correlation between the Buddhist path toward enlightenment and the self-obliteration process. The artist's proclamation during the naked happenings, when she painted the bodies of participants with dots while enticing gawking passersby to join in on the mystical ritual, also bears noting here:

Forget yourself and become one with Nature. Lose yourself in the ever-advancing stream of eternity. Self-obliteration is the only way out. Kusama will cover your body with polka dots. ${ }^{39}$

While self-obliteration held a primarily symbolic meaning in Kusama's Happenings, realizing nirvana in the screenplay required actual destruction in the form of

\footnotetext{
37 "The Gorilla Lady Meets the Demons of Change: A Gen'ei/ Zen Farce," Unpublished typescript (Yayoi Kusama Archive), 1972.

38 Scene Two, Act III, Yayoi Kusama with Gordon Brown, "The Gorilla Lady Meets the Demons of Change: A Gen'ei/ Zen Farce."

39 Manifesto from Anatomic Explosion (Happening staged in front of the George Washington statue across from the New York Stock Exchange, 1968).
} 
bodily annihilation and a mental "surrendering to the state of nothingness and void." ${ }^{40}$ A similar description of the destruction of earthly existence appears in Kusama's 1984 book The Hustlers Grotto of Christopher Street. ${ }^{41}$ Writer Ryū Murakami, reflecting on Kusama's literary talents and comparing them to those of Jean Genet, notes that "both make filth shine." 42 The main character in The Hustlers Grotto, Henry, is a dark-skinned and drug-addicted male prostitute. He is a typical character from Kusama's literary world, a social reject who cannot accept the surrounding reality and for whom the only way out (salvation) is a very physical self-obliterationhis transmutation into a new being. In the final scene of this book, Henry suddenly vanishes:

But the black figure of Henry is no longer there where it's supposed to be, in the corner of the void. ... His body has vanished from the space.... In the milk-colored mist a single black spot. Falling. The spot grows smaller and smaller, until it's just a dark speck dissolving into the mist. ${ }^{43}$

In 1967 Kusama, in collaboration with artist Jud Yalkut, produced, directed, and starred in the experimental film Kusama's Self-Obliteration, which won awards in the United States and Europe, giving her international recognition under the name "Polka-Dot Princess" Kusama. ${ }^{44}$ The film opens with a scene showing the artist painting dots as stick-ons and painting them on various elements in the landscape (e.g., a meadow, the surface of the pond). Note here an expanded notion of self-obliteration, signified by Kusama's addition of nature itself to the process as both a tool and an object. In several scenes, the artist stops placing dots and covers the naked body of a reclining man and a cat with maple leaves. In the next scene, she first places white dots on her body but later she also covers a tree with

40 Yoshimoto, Kusama Saves the World through Self-Obliteration, 3. 41 In 1983, The Hustlers Grotto on Christopher Street won Japan's prestigious Literary Award for New Writers given by the monthly magazine Yasei jidai.

42 Alexandra Munroe's interview with Ryū Murakami, Tokyo, May 21, 1996. Quoted in Alexandra Munroe, "Between Heaven and Earth: The Literary Art of Yayoi Kusama," in Love Forever: Yayoi Kusama 1958-1968, ed. Japan Foundation (Los Angeles: Los Angeles County Museum of Art, 1998), 71.

43 Kusama, The Hustlers Grotto of Christopher Street, 64-5.

44 The film won awards at the 1968 Fourth International Short Film Festival in Belgium, the Second Ann Arbor Film Festival, and the Second Maryland Film Festival. them, imparting the idea that she is to become one with it. We find the symbolic process of annihilation and destruction of earthly superficiality expanded here, encompassing the artist's entire surrounding. Subsequent scenes portray dots succumbing to a continuous and relentless multiplication process, covering buildings, cities, and people, multiplying so fast that at the end they cover nearly everything and everyone. ${ }^{45}$

We might also be able to "hear" Buddhism in the film. The soundtrack is generated by a self-playing music machine, created by an avant-garde musician Joe Jones of the group Fluxus, that sounds like a "chorus of almost 30 amplified frogs." ${ }^{46}$ Among the mysterious sounds are mantras reminiscent of chanting monks.

Participation in Happenings, which appear in the second part of the film, is encouraged in a special press notice: "Extermination, Emptiness, Nothingness, Infinity, [and] Endless." ${ }^{47}$ As noted by Yoshimoto, "These catchy words were used in the advertisement to attract the hippie generation who were drawn to eastern philosophies and mysticism." ${ }^{48}$

Kusama's experimental movie not only extends the self-obliteration idea but also stands as a kind of retrospective of her works from the 1950s and 1960s. By including light show happenings, moreover, Kusama's Self-Obliteration seems to foreshadow her most developed series of happenings, "Body Festival" (1967-70, figure 5).

\section{Mindfulness}

Let us lastly consider Kusama's creativity in the context of psychotherapy and Zen Buddhism by looking at Takahashi Ryūtarō's ongoing exhibition "Takahashi Collection: Mindfulness!” Takahashi, a Japanese psychiatrist and leading collector of modern art, owns over two thousand works of art created by Japanese artists, mainly young people whom he promoted domestically and internationally. Takahashi's "Mindfulness!" series, held in Kagoshima at Kirishima's Open-Air Museum

\footnotetext{
45 Earlier works of the artist and favorite motifs appear in short shots of the film, making the movie something of a small retrospective of Kusama's creativity.

46 Kusama, quoted in Jud Yalkut, "Polka Dot Way of Life," 9.

47 Yayoi Kusama, Press release for "Self-Obliteration," held at The Gate Theater, New York, June 16-17, 1967.

48 Yoshimoto, "Kusama Saves the World through Self-Obliteration,"
} 7. 


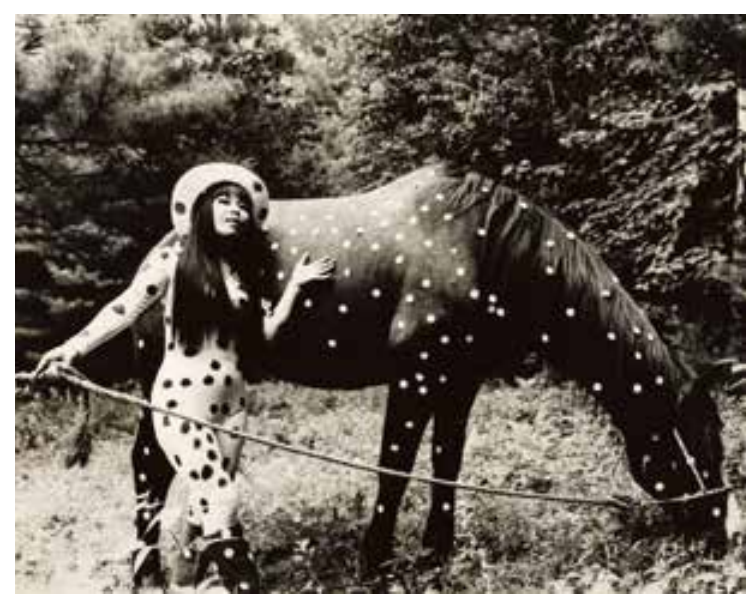

Figure 5. Self-Obliteration Horse Play. 1957. Photography. Performance. Woodstock, New York. CYayoi Kusama.

and in the Sapporo Art Park in 2013, Nagoya City Art Museum in 2014, and the Museum of Art, Kochi in 2016-17, was the collector's second exhibition effort. His first exhibition, "Neoteny Japan," staged in seven museums around the country, already showed this project's potential. It attracted the attention of numerous visitors and critics, which resulted in the increased scale of the second exhibition. This second exhibition featured approximately one hundred works from his private collection by some forty artists. Fourteen works by Kusama took center stage; they ranged from watercolors and drawings from the 1950 os to giant sculptures such as Hi, Konnichiwa Yayoi-chan. ${ }^{49}$

When Takahashi first began to build his collection, he purchased works by Makato Aida and Kusama. Takahashi recalled:

In 1997 I saw an exhibition of new work by Kusama. At about the same time, a show of new work by Makoto Aida was being held at Mizuma Art Gallery. So, in a short time I saw work by someone I thought was a star and also an important up-and-coming artist. That lit the spark within me. ${ }^{50}$

49 Uchida Mayumi, "Takahashi korekushon no kiseki: 'Neotenī' kara 'Maindofurunesu!' e," in Takahashi korekushon: Maindofurunesu I Takahashi Collection Mindfulness!, eds. Abe Ken'ichi and Oshigane Junshi (Tokyo: Bijutsu Shuppansha, 2013), 12.

50 Quoted in Edan Corkill, "Collector Steps into the Void: With Museums Gone AWOL, Ryutaro Takahashi Snapped up Amazing
Takahashi further reminisced about the great impression her works made on him in the 1960s, adding that for him and for the artistic environment of the time, which was swallowed by the spirit of the counterculture, Kusama, a "singularly battling in New York woman," was "someone of a muse." 51

Mindfulness, translated from the Pali sati (Jpn. nen 念), connotes Buddhist meditation practice and constitutes one of the vital seven factors of enlightenment (Skt. sapta bodhyanga). ${ }^{52}$ Mindfulness denotes a method of seeing things as they really are, without the participation of the Cartesian thinking ego. The thinking ego must be turned off (a form of self-obliteration) in order to make way for a newly expanded and mindful consciousness. Muhō Noelke, abbot of Antaiji 安泰 寺, explains it in the following manner:

... we have to forget things like "I should be mindful of this or that". If you are mindful, you are already creating a separation ("I - am - mindful - of - ....”). Don't be mindful, please! When you walk, just walk. Let the walk, walk. Let the talk, talk (Dogen Zenji said: "When we open our mouth, it is filled with Dharma"). Let the eating eat, the sitting sit, the work, work. Let sleep sleep. ${ }^{53}$

Takahashi's exhibit similarly encouraged viewers to perceive the art as it is, to notice things here and now without the social and cultural entanglements such as assessments, contexts, or convictions. ${ }^{54}$ In Takahashi's words, "perhaps then, things which until now we acknowledged as art will be perceived by us completely differently. Or perhaps things which we perceived until

Artworks," Japan Times, May 22, 2009, http://www.japantimes. co.jp/culture/2009/05/22/culture/collector-steps-into-the-void/ (accessed January 10, 2017).

51 Takahashi Ryūtarō and Aida Makoto, "Aida Makoto to Takahashi Ryūtarō: Āto no rekishi wa 'kidzuki' no rekishi. Sore ga 'Maindofurunesu!'"' in Takahashi korekushon: Maindofurunesu / Takahashi Collection Mindfulness!, eds. Abe and Oshigane,133.

52 The other factors include investigation, energy, joy, tranquility, concentration, and equanimity. See Buddhaghosa, trans. Bhadantacariya and Bhikkhu Ñannamoli, The Path of Purification: Visuddhimagga (Seattle, WA: BPE Pariyatti Editions, 1999).

53 Muhō Noelke, "Adult Practice: Part 18, Stop Being Mindful," http://antaiji.org/archives/eng/adult18.shtml (accessed January 10, 2017).

54 Takahashi Ryūtarō, "'Takahashi korekushonten no maindofurunesu!' ni yosete," in Takahashi korekushon: Maindofurunesu I Takahashi Collection Mindfulness!, eds. Abe and Oshigane, 7. 


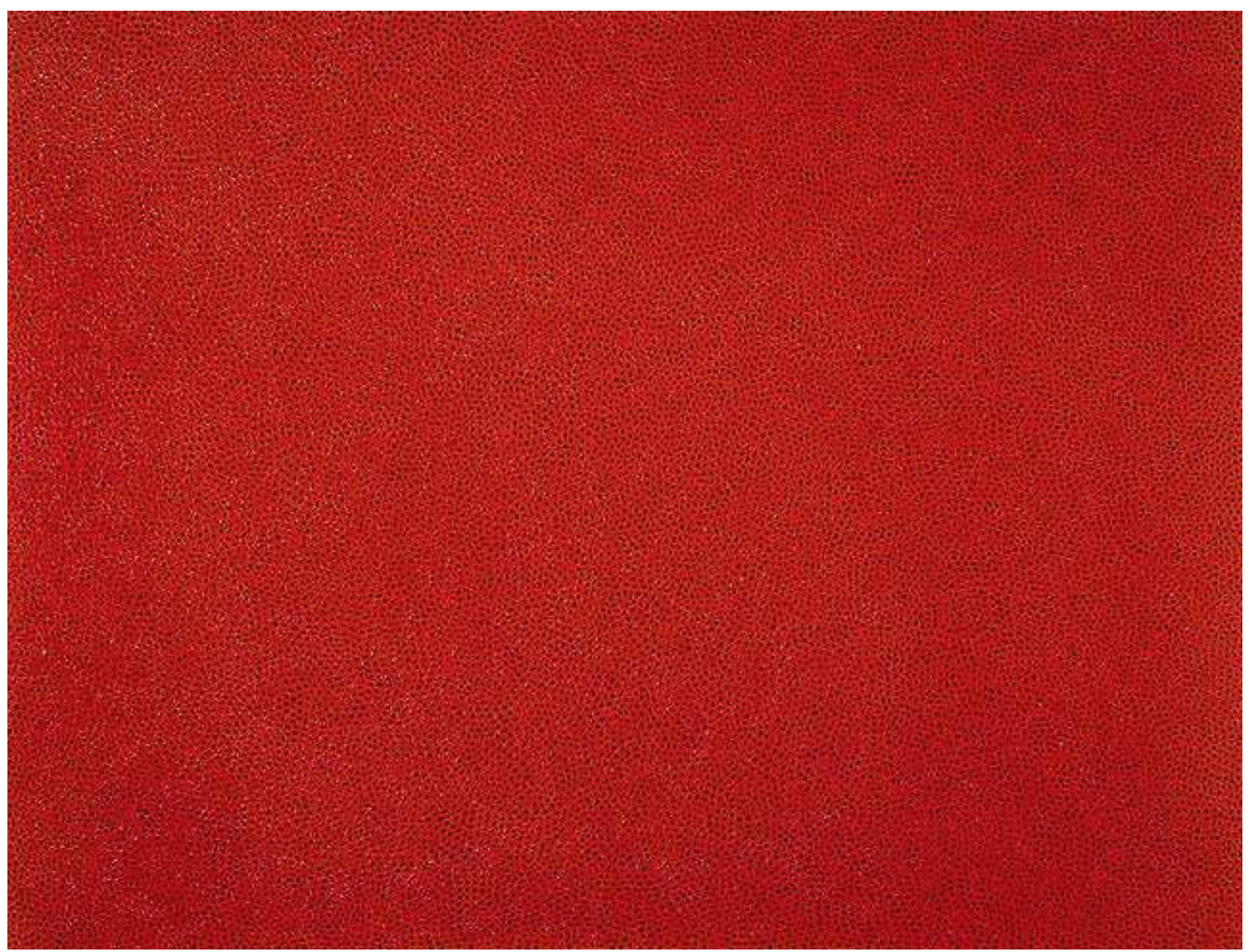

now as not [?] art will become art." ${ }^{35}$ For Takahashi, an art exhibit should be the site of an as-yet-unfulfilled meeting of various generations of artists, both youths still unknown to a wide public and "veterans" whose names appear in the programs of the most important galleries and museums in the world. "That is why all the more I would like to see their [the artists'] joint works in a freed state of mindfulness." ${ }^{.6}$

55 This way of viewing art, unburdened by history and context, had already been discussed in Western and Japanese art history. In the twentieth century, for example, Marcel Duchamp introduced "ready-made" objects such as a urinal and called them works of art. In sixteenth-century Japan, tea master Sen no Rikyū's 千利休 (1522-91) chamber pot was used as a flower vase during a Japanese traditional tea ceremony. In both cases, we see radical acts that draw on new and different ways of viewing familiar objects. Takahashi, "'Takahashi korekushonten no maindofurunesu!' ni yosete," 7 .

$56 \mathrm{lbid}$
Figure 6. Kusama Yayoi. Infinity Nets (TOOTAAZ). 2008. H. 194cm, w. $259 \mathrm{~cm}$. Acrylic on canvas. OYayoi Kusama.

Takahashi's vision of treatment through art is part of his "Mindfulness!" exhibit as well. Takahashi's plan for his art collection also included a therapeutic dimension. ${ }^{57}$ By placing artwork in medical centers and

57 Jon Kabat-Zinn, professor in the Medical Department at the University of Massachusetts and the founder of the Center for Mindfulness in Medicine, Health Care, and Society, created a method of therapy called Mindfulness-Based Stress Reduction. Kabat-Zinn's therapy aims to free patients of automatic thoughts, feeling, and reactions that create stress, depression, and negative habits. Looking at one's ailments from the "outside," Kabat-Zinn argues, can be a means of overcoming our patterns of the mind and ridding patients of various ailments. Jon Kabat-Zinn, Mindfulness for Beginners: Reclaiming the Present Moment-and Your Life (Louisville: Sounds True, 2012). 
making them available for patients to enjoy, Takahashi conceived of art as playing a key role in psychological and psychiatric treatment. ${ }^{58}$ Takahashi's view of art resonates well with Kusama's frequently repeated slogans about the need to nurture love and peace as well as free ourselves from the shackles imprisoning people (by surrendering to self-obliteration).

Today, many people take the path of gluttony, or lust, or greed, flailing and floundering as they vie for worldly fame. In such a society, seekers of truth find that their burden is great and the road steep and hard. But that is all the more reason for us to seek a rosier future for the soul. ${ }^{59}$

\section{Self-Obliteration $=$ Enlightenment (?)}

"But my paintings had nothing to do with Impression-

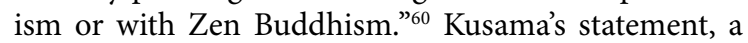
reflection on her Infinity Nets (figure 6), unequivocally contradicts any overt connection to Buddhism. I have argued here, however, that conscious references nevertheless emanate from many of her artistic undertakings. The correspondence may not be exact in the above equation, but the ever-evolving world of Kusama Yayoi-a multitude of entrances, exits, and their subsequent perceptions - compels us to at least entertain the idea of an expanded observation.

I continue to fight with every fiber of my being. This is my own peculiar karma and destiny in the world. ${ }^{61}$

\footnotetext{
58 This is not the first instance of a psychiatrist becoming fascinated with Kusama's art and attempting to frame her works in terms of psychiatric discourse. In 1952, Shihō Nishimaru 西丸四方 (1910-2002), one of the first professors of psychiatry at Shinshu University, presented Kusama's works during a conference of the Kantō Society of Psychiatry and Neurology in a presentation entitled: "The Genius of a Schizoid Female Patient." Shibutami Akira, "The Eternal Spirit Dancing in the Flower Garden," in Yayo Kusama: Eternity of Eternal Eternity, ed. Masahiro Yasugi et al. (Tokyo: Asahi Shimbun, 2013), 154-55; Takahashi and Aida, "Aida Makoto to Takahashi Ryūtarō," 133.

59 Kusama, Infinity Net, 211.

60 Kusama, "Interview with Gordon Brown (extract) 1964," in Yayoi Kusama, eds. Laura Hoptman, Tatehata Akira, and Udo Kultermann (New York: Phaidon Press, 2011), 103.

61 Kusama, Infinity Net, 212
}

\section{Bibliography}

Buddhaghosa, trans. Bhadantacariya and Bhikkhu Ñannamoli. The Path of Purification: Visuddhimagga. Seattle, WA: BPE Pariyatti Editions, 1999.

Corkill, Edan. "Collector Steps into the Void: With Museums Gone AWOL, Ryutaro Takahashi Snapped up Amazing Artworks." Japan Times, May 22, 2009. http://www.japantimes.co.jp/culture/2009/05/22/culture/collector-stepsinto-the-void/ (accessed January 13, 2017).

Derrida, Jacques, trans. Adam Dziadek, and Pawel Janusz Margański. Marges de la philosophie. Warsaw: Wydawnictwo KR, 2002.

Durix, Claude. Cent clés pour comprendre le zen. Paris: Courrier du Livre, 1991.

Ikai Hisashi 猪飼尚司. “Mizutama ni komerareta imi o tokiakasu 水玉に込められた意味を、解き明かす.” In Yappari suki da! Kusama Yayoi やつぱり好きだ! 草 間爾生. Edited by Pen Henshūbu ペン編集部, 46-51. Tokyo: Hankyū komyunikēshonzu, 2011.

Kabat-Zinn, Jon. Mindfulness for Beginners: Reclaiming the Present Moment - and your Life. Louisville: Sounds True, 2012.

Kusama Yayoi 草間彌生. “Interview with Gordon Brown (extract) 1964." In Yayoi Kusama. Edited by Laura Hoptman, Tatehata Akira, and Udo Kultermann, 100-4. New York: Phaidon Press, 2011.

- Mugen no ami 無限の網. Tokyo: Sakuhinsha, 2011.

_ , trans. Ralph McCarthy. Infinity Net: The Autobiography of Yayoi Kusama. London: Tate Publishing, 2011 (2002).

. "The Artist's Voice Since 1981." Conversation with Turner Grady. Bomb (Winter 1999): 13-6.

_ . "CICA/YK/600o.o8." 1989 exhibition, Center for International Contemporary Arts (CICA), New York.

——. "Atorie hōmon Kusama Yayoi アトリエ訪問草間彌

生.” Co•La•Bo Art 2 (May 1994): 47-52.

. Kurisutofā danshōkutsu クリストファー男娼窟.

Tokyo: Jishiritsu Shobō, 1989.

- trans. Ralph McCarthy. The Hustlers Grotto of Christopher Street. Berkeley, CA: Wandering Mind Books, 1997 (1983).

, with Gordon Brown. "The Gorilla Lady Meets the Demons of Change: A Gen'ei/ Zen Farce.” Unpublished typescript. 1972.

. "Nudist Queen Designs Clothes for Department Store.” Press release. Kusama Fashion Incorporated. April, 1969. 
"Homosexual Wedding." Press release. Kusama Polka Dot Church. November 25, 1968.

__ "Manifesto from Anatomic Explosion" (Happening staged in front of the George Washington across from the New York Stock Exchange). Self-published, 1968.

. "Open Letter to My Hero, Richard M. Nixon." Self-published letter. November 11, 1968.

- Press release for "Self-Obliteration." The Gate Theater, New York. June 16-17, 1967.

“Shiatoru tayori シアトル便り.” Nanshin nichi nichi shinbun 南信日日新聞. January 30, 1958.

"Letter to Kusama Productions from Kenneth Waissman of Waissman \& Fox Inc." October 12, 1972. Yayoi Kusama Archive.

Levine, Gregory. "Two (or More) Truths: Reconsidering Zen Art in the West." In Awakenings: Zen Figure Paintings from Medieval Japan. Edited by Gregory Levine and Yukio Lippit, 52-63. New York: Japan Society, 2007.

Munroe, Alexandra. "Between Heaven and Earth: The Literary Art of Yayoi Kusama." In Love Forever: Yayoi Kusama 1958-1968. Edited by Japan Foundation, 71-85. Los Angeles: Los Angeles County Museum of Art, 1998.

Neri, Louise, ed. Yayoi Kusama. New York: Rizzoli, 2012. Russell, Bertrand. History of Western Philosophy. London and New York: Routledge Classics, 2006.

Shibutami Akira. "The Eternal Spirit Dancing in the Flower Garden.” In Yayoi Kusama: Eternity of Eternal Eternity. Edited by Masahiro Yasugi et al., 52-157. Tokyo: Asahi Shinbun, 2013.

Takahashi Ryūtarō 高橋龍太郎. “'Takahashi korekushonten no maindofurunesu!' ni yosete「高橋コレクション展 マインドフルネス! 」に寄せて.” In Takahashi korekushon: Maindofurunesu 高橋コレクション: マイン ドフルネス! / Takahashi Collection Mindfulness! Edited by Abe Ken'ichi 阿部健一 and Oshigane Junshi 押金純 士, 6-7. Tokyo: Bijutsu Shuppansha, 2013.

Takahashi Ryūtarō and Aida Makoto会田誠. “Aida Makoto to Takahashi Ryūtarō: Āto no rekishi wa 'Kidzuki' no rekishi. Sore ga 'Maindofurunesu!' 会田誠と高橋龍太 郎一アートの歴史は「気づき」の歴史。それが「マ インドフルネス! 」.” In Takahashi korekushon: Maindofurunesu / Takahashi Collection Mindfulness! Edited by Abe Ken'ichi and Oshigane Junshi, 131-37. Tokyo: Bijutsu Shuppansha, 2013.

Takiguchi Shūzō 滝口修造. “Yōseiyo eien ni 妖精よ永遠 に.” In Manhattan jisatsu misui jōshūhan マンハッタ ン自殺未遂常習犯. Edited by Kusama Yayoi, 345-49. Tokyo: Kadokawa Bunko, 1984
Uchida Mayumi 内田真由美. “Takahashi korekushon no kiseki: 'Neotenī' kara 'Maindofurunesu!' e 高橋コレクシ ヨンの軌跡一「ネオテニー・ジャパン」から「マイ ンドフルネス!」へ.” In Takahashi korekushon: Maindofurunesu / Takahashi Collection Mindfulness! Edited by Abe Ken'ichi and Oshigane Junshi, 8-13. Tokyo: Bijutsu Shuppansha, 2013.

Watts, Alan. Beat Zen, Square Zen, and Zen. San Francisco: City Lights Books, 1959.

Westgeest, Helen. Zen in the Fifties. Chicago: Reaktion Books, 1998.

Wilkinson, Richard H. Egyptian Scarabs. London: Shire Publications, 2008.

Yalkut, Jud. "Polka Dot Way of Life (Conversations with Yayoi Kusama).” New York Free Press 1, no. 8 (1968): 9-10.

Yamamura, Midori. Yayoi Kusama: Inventing the Singular. Cambridge, MA: The MIT Press, 2015.

. "Re-Viewing Kusama 1950-1975: Biography of Things." In Yayoi Kusama Mirrored Years. Edited by Franck Gautherot, 66-113. Dijon: Le Consortium, 2009.

Yoshimoto, Midori. "Kusama Saves the World through Self-Obliteration." Self-published. 2011. https://www. academia.edu/2092612/Kusama_Saves_the_World_ Through_Self-Obliteration_English_version_(accessed January 20, 2017). 